\title{
ELECTROLYTIC PRODUCTION OF URANOUS NITRATE
}

\author{
E. G. OREBAUGH \\ R. C. PROPST
}

Approved by

M. L. Hyder, Research Manager

Analytical Chemistry Division

S. D. Harris, Jr., Research Manager

Actinide Technology Division

Publication Date: April 1980

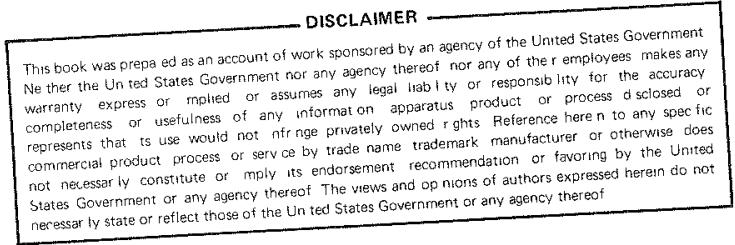

E. I. du Pont de Nemours \& Co. Savannah River Laboratory Aiken, SC 29808

PREPARED FOR THE U. S. DEPARTMENT OF ENERGY UNDER CONTRACT DE-ACO9-76SRO0001 
ABSTRACT

Efficient production of uranous nitrate is important in nuclear fuel reprocessing because U(IV) acts as a plutonium reductant in solvent extraction and can be coprecipitated with plutonium and/or thorium as oxalates during fuel reprocessing.

Experimental conditions are described for the efficient electrolytic production of uranous nitrate for use as a reductant in the SRP Purex process. The bench-scale, continuousflow, electrolysis ce11 exhibits a current efficiency approaching $100 \%$ in combination with high conversion rates of U(VI) to U(IV) in simulated and actual SRP Purex solutions. High current efficiency is achieved with a voltage-controlled mercuryplated platinum electrode and the use of hydrazine as a nitrite scavenger. Conversion of U(VI) to U(IV) proceeds at $100 \%$ efficiency. Cathodic gas generation is minimal. The low rate of gas generation permits a long residence time within the cathode, a necessary condition for high conversions on a continuous basis.

Design proposals are given for a plant-scale, continuousflow unit to meet SRP production requirements. Results from the bench-scale tests indicate that an $8 \mathrm{~kW}$ unit can supply sufficient uranous nitrate reductant to meet the needs of the Purex process at SRP. 


\section{CONTENTS}

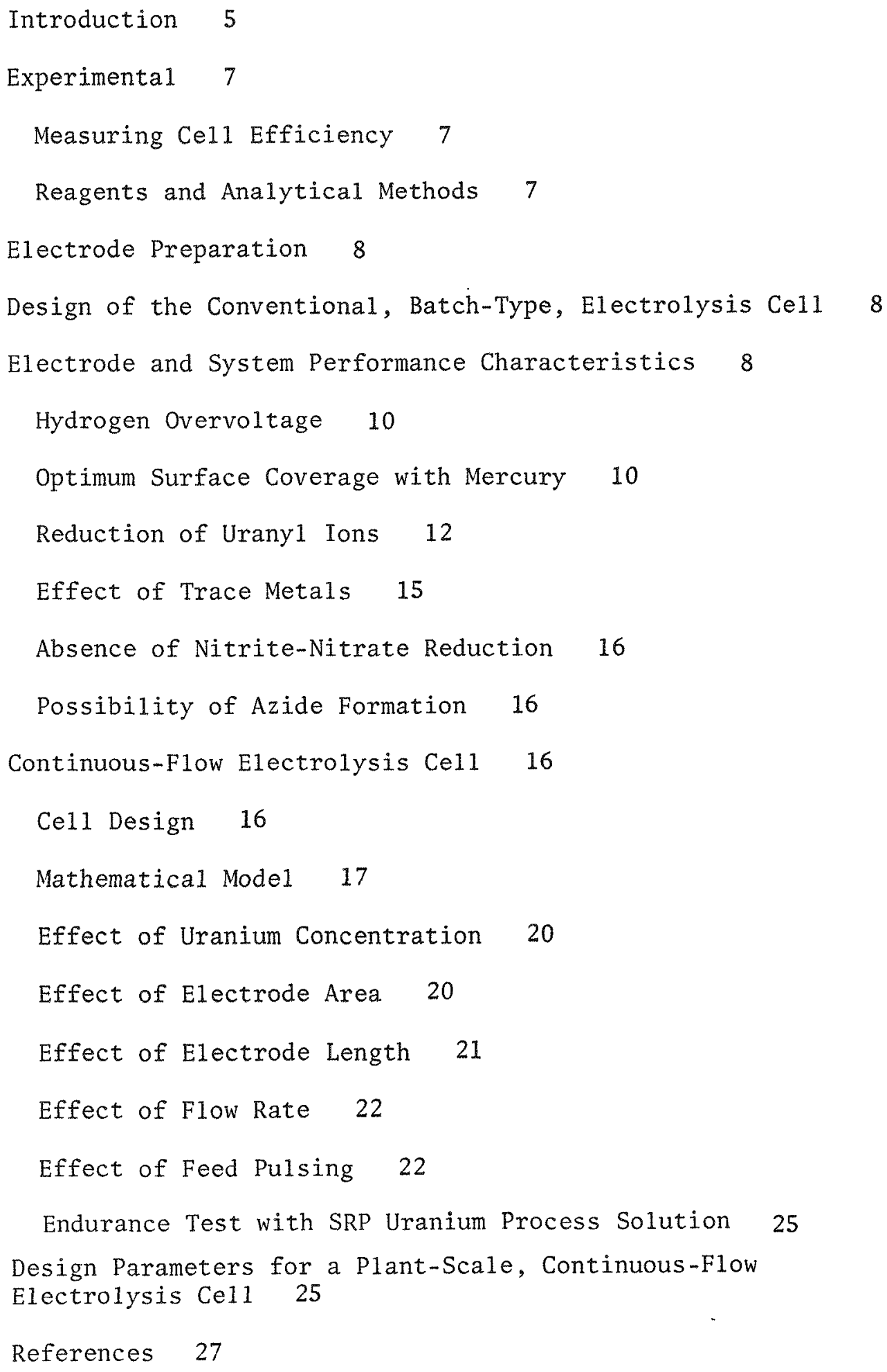




\section{LIST OF FIGURES}

1 Conventional (Batch) Electrolysis Cell 9

2 Increase in Hydrogen Overvoltage with Increasing Mercury Coverage of a Platinum Mesh Electrode 11

3 Voltammetric Curves for U(IV) Production in a Batch Electrolytic Cell Having Mercury-Coated, Platinum-Mesh Electrodes 13

4 Decrease of Current with Time for Solutions of Various Uranium, Nitric Acid, Oxygen, and TBP Concentrations 14

5 Assembly of the Bench-Scale, Continuous-Flow Electrolysis Cel1 18

6 Graph of Equation 18 for Reduction of a $0.3 \mathrm{M}$ Uranyl Nitrate Solution in the Bench-Scale, ContinuousFlow Electrolysis Cell 23

7 Conversion of Uranyl Nitrate to Uranous Nitrate in a Bench-Scale, Continuous-Flow Electrolys is Cell 24

8 A Proposed Cathode Design for a Plant-Scale, Continuous-Flow Electrolysis Cell for Reducing $\mathrm{U}(\mathrm{VI})$ to $\mathrm{U}(\mathrm{IV}) \quad 26$

\section{LIST OF TABLES}

1 Effect of Uraniun Concentration on Conversion Efficiency 20

2 Effect of Electrode Area 21

3 Effect of Electrode Length 21 


\section{ELECTROLYTIC PRODUCTION OF URANOUS NITRATE}

\section{INTRODUCTION}

An efficient electrolytic method for the production of uranous nitrate solutions is needed to support conceptual design changes in the Purex and related solvent extraction processes at the Savannah River Plant (SRP).

In the SRP Purex process, plutonium and uranium are extracted from an oxidizing nitric acid solution into an organic tributyl phosphate (TBP) phase as Pu(IV) and U(VI) nitrates. Partitioning of the plutonium and uranium is achieved by backextracting the plutonium into a reductive nitric acid solution as $\mathrm{Pu}$ (III). The $\mathrm{Pu}$ (III)-TBP complex is sufficiently less stable than other TBP complexes of U(VI), U(IV), or Pu(IV) that quantitative separations can be attained by multistage, countercurrent extraction. Ferrous sulfamate is utilized in the current SRP Purex process. The ferrous ion functions as the reductant for plutonium to produce $\mathrm{Pu}$ (III), and the sulfamate stabilizes the $\mathrm{Pu}$ (III) and $\mathrm{Fe}(\mathrm{II})$ ions in the normally oxidizing nitric acid media.

A large excess ( 40 fold) of ferrous sulfamate is commonly required to achieve acceptable separations efficiencies; therefore, this reagent becomes the largest single source of solids in the waste from the process. Substitution of electrochemically prepared U(IV) as a reductant for plutonium(III) would eliminate the introduction of iron to the waste; and substitution of hydrazine for sulfamic acid would further reduce the waste solids, since hydrazine is converted to entirely gaseous products upon heating, rather than forming nonvolatile sulfates as does the sulfamic acid. The economic costs of radioactive waste processing and storage will serve to justify the process changes.

Uranous nitrate has been proposed as a reductant for use in solvent extraction processes since the inception of the Purex process. ${ }^{1}$ Numerous investigations of the electrolytic preparation of uranous nitrate have been reported. ${ }^{2-8}$ However, none of the reported processes exhibited both high current efficiency and high conversion rates for converting uranyl ions to U(IV) ions. Indeed, the current efficiency for the in-situ electrolytic process to be used at the Allied-General Nuclear Services Plant at Barnwe11, South Carolina, is estimated to be about $60 \%{ }^{3}$ 
In-situ generation of uranous nitrate in existing SRP process equipment would be prohibitively costly because extensive modifications would be required. Thus, for SRP applications, a continuous process for the electrolytic generation of uranous nitrate from a diverted product stream is necessary. The process must be highly efficient to minimize power consumption and to ensure against excessive gassing and the production of excessive amounts of nitrites and other undesirable species. SRP requirements include a production rate of about 80 1iters/ hour of a solution that is $0.95 \mathrm{M}$ in uranous nitrate. Thus, for a product stream that is IM in uranyl nitrate, a $95 \%$ conversion will be required.

Conversion efficiency is a function of the mass transfer processes within the electrolytic cell, the electron transfer process for the uranyl ion, and the nature of the electron transfer processes which occur at the electrode surface. Competing processes such as nitrate reduction and hydrogen evolution must be minimized if high current efficiencies are to be realized.

Several different electrode materials were evaluated for the electrogeneration of uranium(IV). ${ }^{2-8}$ Except for platinum and mercury, none of the materials permitted current efficiencies approaching $100 \%$. However, both platinum and mercury were considered undesirable as electrode materials. Platinum depends on the formation of a layer of hydrous uranous oxide ${ }^{5}$ to suppress hydrogen evolution. The stability of this layer is $\mathrm{pH}$ dependent, and very little is known concerning the effects of coprecipitated trace impurities. Mercury presents engineering design problems and a waste disposal and/or recovery problem if large quantities are involved. T. M. Florence ${ }^{9}$ has utilized in-situ plating of mercury to enhance the stripping analysis of trace metals. The amount of mercury involved was quite small, covering the electrode with a thin film 0.001 to $0.01 \mathrm{\mu m}$ thick. It thus appeared than an in-situ, mercury-plated platinum electrode would combine the advantages of both mercury and platinum. Because the SRP electrolyte solution would contain hydrazine to stabilize uranium(IV) and prevent its reoxidation by nitrites, no difficulties from the catalyzed reduction of nitrites by trace metals deposited in the mercury layer was anticipated.

Published studies were available on the electrochemistry of uranium, ${ }^{-8}$ the stability of uranous nitrate solutions, 2,10 and the nature of mercury-plated platinum electrodes. ${ }^{1-13}$ However, it was necessary to show the applicability of the mercuryplated platinum electrode (MPPE) for use with plant uranium solutions and to demonstrate a bench-type model of a fully functional, continuous-flow electrolysis cell. 
- Two types of electrochemical cells were evaluated: a conventional batch-type electrolysis cell with a large separator between the anode and cathode compartments, and a bench-scale, continuous-flow cell.

\section{EXPERIMENTAL}

\section{Measuring Cel1 Efficiency}

For a typical electrolysis experiment, the extent of uranyl ion conversion efficiency and the current efficiency were determined by a combination of electrochemical and chemical techniques. During the electrolysis, the potential difference between the working and reference electrodes was held constant by means of a potentiostat, and the electrolysis and integrated electrolysis currents were recorded on a strip chart recorder using an electronic integrator. The electronic integrator was fabricated at the Savannah River Laboratory (SRL) and was based on conventional operational amplifier circuitry.

Al1 potentials were referred to the mercury/mercurous sulfate $\left(1 \mathrm{M} \mathrm{H}_{2} \mathrm{SO}_{4}\right)$ reference electrode (MSE). This electrode had a potential of $+0.41 \mathrm{~V} v \mathrm{v}$. the saturated calomel electrode in $2 \mathrm{M}$ nitric acid solution.

Reagents and Analytical Methods

Reagent-grade chemicals were used throughout this study. Laboratory nitrogen (water-pump grade) was used when sparging the solutions.

Chemical analysis for total uranium was based on reduction of all the soluble uranium in a lead column, followed by oxidative titration with ceric ammonium sulfate. The electrically generated uranous ion was determined by direct titration with ceric ammonium sulfate. The conversion efficiency was expressed as the ratio of the uranous content of the product stream to the total uranium content. Current efficiencies were expressed as the ratio of the uranous content as determined by titration to the theoretical maximum calculated from the integrated current.

Other analyses employed in this study were total acidity (utilizing fluoride complexation of the uranium), hydrazine (by an iodometric procedure), and nitrite ion concentration (by potentiometry). Attempts to determine hydrazoic acid were unsuccessful; however, the results of hydrazine analyses showed that negligible amounts of this substance were consumed under the optimum operating conditions. 


\section{ELECTRODE PREPARATION}

The following procedure was employed to electroplate mercury onto the cathodes prior to use. The electrodes were first immersed in a $1 \mathrm{M}$ nitric acid - $0.5 \mathrm{M}$ nitrous acid solution with agitation until the surface of the platinum appeared shiny and bright. The cathode compartment was then rinsed thoroughly and filled with $0.2 \mathrm{M}$ solution of hydrazine in $2 \mathrm{M}$ nitric acid. This solution contained sufficient mercuric nitrate to coat the cathode with about $150 \mu \mathrm{g} / \mathrm{cm}^{2}$ of mercury.* The solution was immediately electrolyzed at $-0.7 \mathrm{~V}$ vs. the mercurous sulfate electrode (MSE) with agitation until the background current had decayed to a constant value.

Electrodes prepared in this manner could be left standing in dilute nitric acid solution for short periods and used repeatedly without loss of hydrogen overvoltage. Occasionally, due to the loss of potential control, an electrode would become discolored and excessive gassing would result. These electrodes were readily returned to service by repeating the cleaningplating procedure.

DESIGN OF THE CONVENTIONAL, BATCH-TYPE, ELECTROLYSIS CELL

A conventiona1, batch-type, electrolysis ce11 (Figure 1) was designed and operated to test the characteristics of the mercury-plated platinum (MPPE) electrodes. This cell had a reductive volume of $15 \mathrm{~mL}$, and contained a relatively large separator between the anode and cathode compartments. The porous separator was fabricated from unfired Vycor ${ }^{(B)}$ glass (Corning Glass Works, Corning, NY). Both the cylindrical anode and cathode were fabricated from 45-mesh platinum screen suspended from 14-gage platinum bus wires. The reference electrode used to monitor the cathode potential was positioned in a region of minimum current-flux within the cathode. Mass transfer within the cathode compartment was assisted by a small paddle-wheel stirrer.

\section{ELECTRODE AND SYSTEM PERFORMANCE CHARACTERISTICS}

The batch-type cell was used to determine characteristics of the MPPE as well as the electrochemistry of simulated pro-

* The amount of mercury $\left(\mu \mathrm{g} / \mathrm{cm}^{2}\right)$ for preparing the mercuryplated platinum electrode should be minimal because of the associated waste disposal problems and the possible explosion hazard from the formation of mercurous azide at the electrode. 


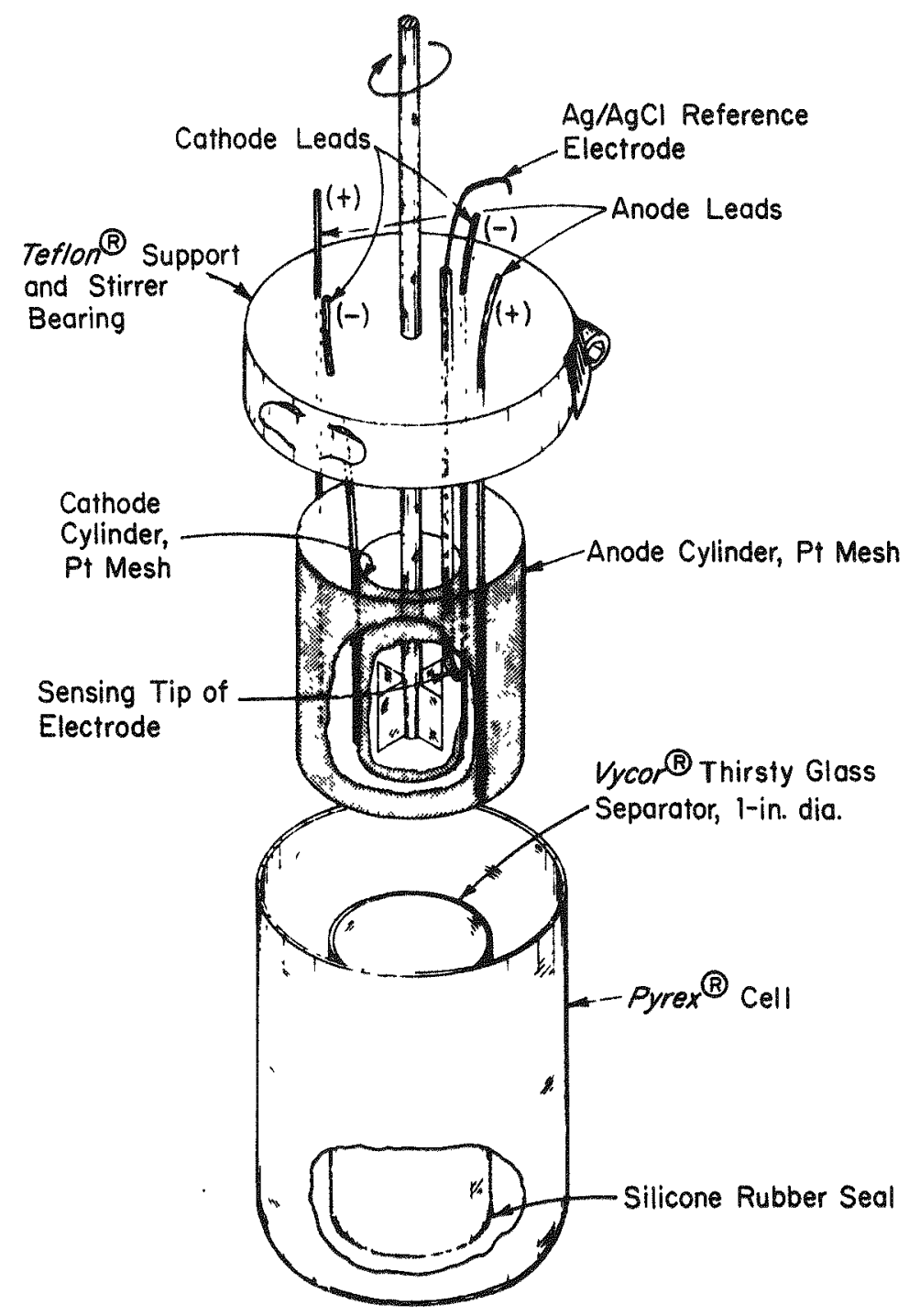

FIGURE 1. Conventional (Batch) Electrolysis Cell 
cess solutions. The following dependent and independent variables were investigated:

- Hydrogen overvoltage and mercury deposition.

- Optimum surface coverage of mercury.

- Reduction of uranyl ions.

- Effect of trace metals.

- Possible reduction of nitrite and nitrate ions.

- Possibility of forming mercurous azide.

\section{Hydrogen Overvoltage}

Overvoltage is defined as the difference between the observed potential of the electrode at a given current density and the reversible potential for the reaction. We find, in agreement with other workers, 11-13 that the overvoltage for hydrogen at the mercury-plated platinum electrode (MPPE) is intermediate between that for hydrogen-on-platinum and that for hydrogen-on-mercury, and is dependent on the amount of mercury deposited.

The overvoltage behavior of the MPPE as a function of the amount of deposit $\left(\mathrm{mg} / \mathrm{cm}^{2}\right)$ is illustrated in Figure 2. The overvoltage was measured at a current density of $1 \mathrm{~mA} / \mathrm{cm}^{2}$ and corrected for the potential of the untreated platinum electrode. The change in overvoltage with coverage was indicative of a nonuniform deposit. Other investigators have reported that: mercury is deposited as discrete droplets, 12 a $\mathrm{PtHg}_{4}$ intermetallic compound forms with time at the mercury-platinum interface, ${ }^{12}$ and the overvoltage for hydrogen-on-Ptig 4 is only 100 to $150 \mathrm{mV}$ cathodic to that for hydrogen-on-platinum. ${ }^{13}$ Thus, the observed overvoltages were attributed to the fractional surface coverages of platinum, $\mathrm{PtHg}_{4}$, and mercury. The overvoltages increase in the order platinum $<\mathrm{PtHg}_{4}<$ mercury.

\section{Optimum Surface Coverage with Mercury}

Figure 2 shows that the overvoltage for hydrogen increases rapidly with surface coverage up to a maximum of $75 \mathrm{mg} / \mathrm{cm}^{2}$, and that an increase in coverage to $150 \mathrm{mg} / \mathrm{cm}^{2}$ results in very little improvement in overvoltage. Nevertheless, a coverage of 150 $\mathrm{mg} / \mathrm{cm}^{2}$ was selected to ensure against loss of overvoltage with time due to the slow conversion of mercury to $\mathrm{PtHg}_{4} .{ }^{11}$ No 


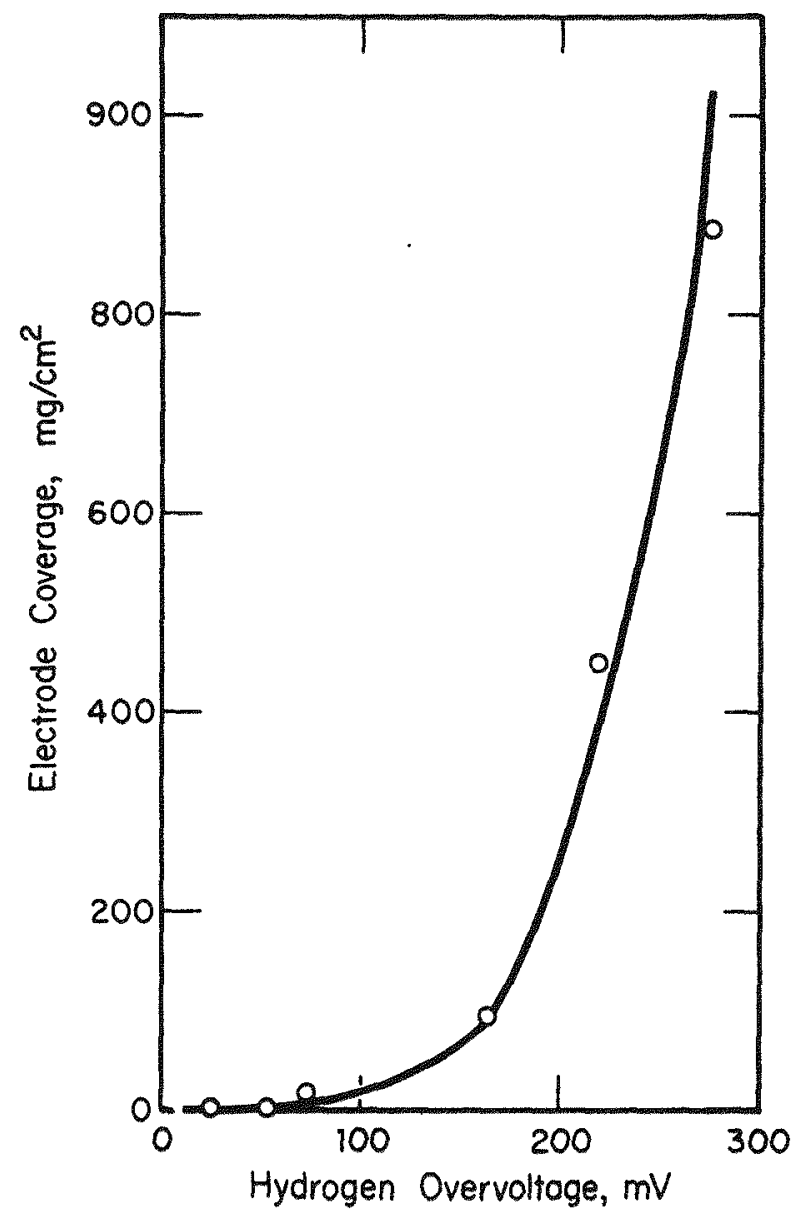

FIGURE 2. Increase in Hydrogen Overvol tage with Increasing Mercury Coverage of a Platinum Mesh Electrode 
serious deterioration of the MPPE with time was observed during this study except as noted in the experimental section. Other investigators report lifetimes for the MPPE which ranged from days to weeks. 11

\section{Reduction of Uranyl Ions}

The uranyl ion was rapidly reduced at the MPPE in stirred solution with a current efficiency of essentially $100 \%$. The effects of dissolved TBP, dissolved oxygen, and trace impurities were minimal.

The electrochemical reduction of uranium(VI) in acid solution has been the subject of numerous investigations. The reaction proceeds in two steps, a reversible electrochemical process followed by a rapid disproportionation:

$$
\begin{aligned}
& \mathrm{UO}_{2}{ }^{{ }^{+}}+\mathrm{e} \rightarrow \mathrm{UO}_{2}{ }^{+} \\
& 2 \mathrm{UO}_{2}{ }^{+}+4 \mathrm{H}^{+} \rightarrow \mathrm{U}^{4+}+\mathrm{UO}_{2}{ }^{{ }^{+}+}+2 \mathrm{H}_{2} \mathrm{O}
\end{aligned}
$$

Thus, in highly acid solution the overall reaction is

$$
\mathrm{UO}_{2}{ }^{2+}+4 \mathrm{H}^{+}+2 \mathrm{e} \rightarrow \mathrm{U}^{4+}+2 \mathrm{H}_{2} \mathrm{O}
$$

The oxidation of $\mathrm{U}^{4+}$ involves the formation of oxygen bridges; therefore, Equation 3 is highly irreversible.

A typical voltammetric curve for the reduction of $0.2 \mathrm{M}$ uranyl nitrate in $0.2 \mathrm{M}$ hydrazine-2M nitric acid solution is shown in Figure 3. The curve exhibits a limiting current plateau of $\sim 150 \mathrm{mV}$ where the uranium(VI) reduction proceeds at essentially $100 \%$ current efficiency. Indeed, current efficiencies of $100 \pm 1$ percent were observed when the electrolysis potential was within the plateau range $(-0.65$ to -0.8 volts $)$.

The effects of the uranium concentration, acidity, dissolved oxygen, and suspended organic matter (TBP) on the reduction rate for the uranyl ion were determined from graphs of the logarithm of the electrolysis current vs. electrolysis time (Figure 4). These electrolyses were carried out in the conventional cell (Figure 1). According to the coulometric equation, ${ }^{14}$ the intercept of the $\log$ of current vs. time curve is proportional to the initial uranium concentration, and the slope of this curve is a measurement of the reaction rate.

Thus, these results indicate: (1) that the initial electrolysis current (at constant acidity) is proportional to the uranium concentration, (2) that the reaction rate increases with acidity in agreement with Equation 3, (3) that dissolved 


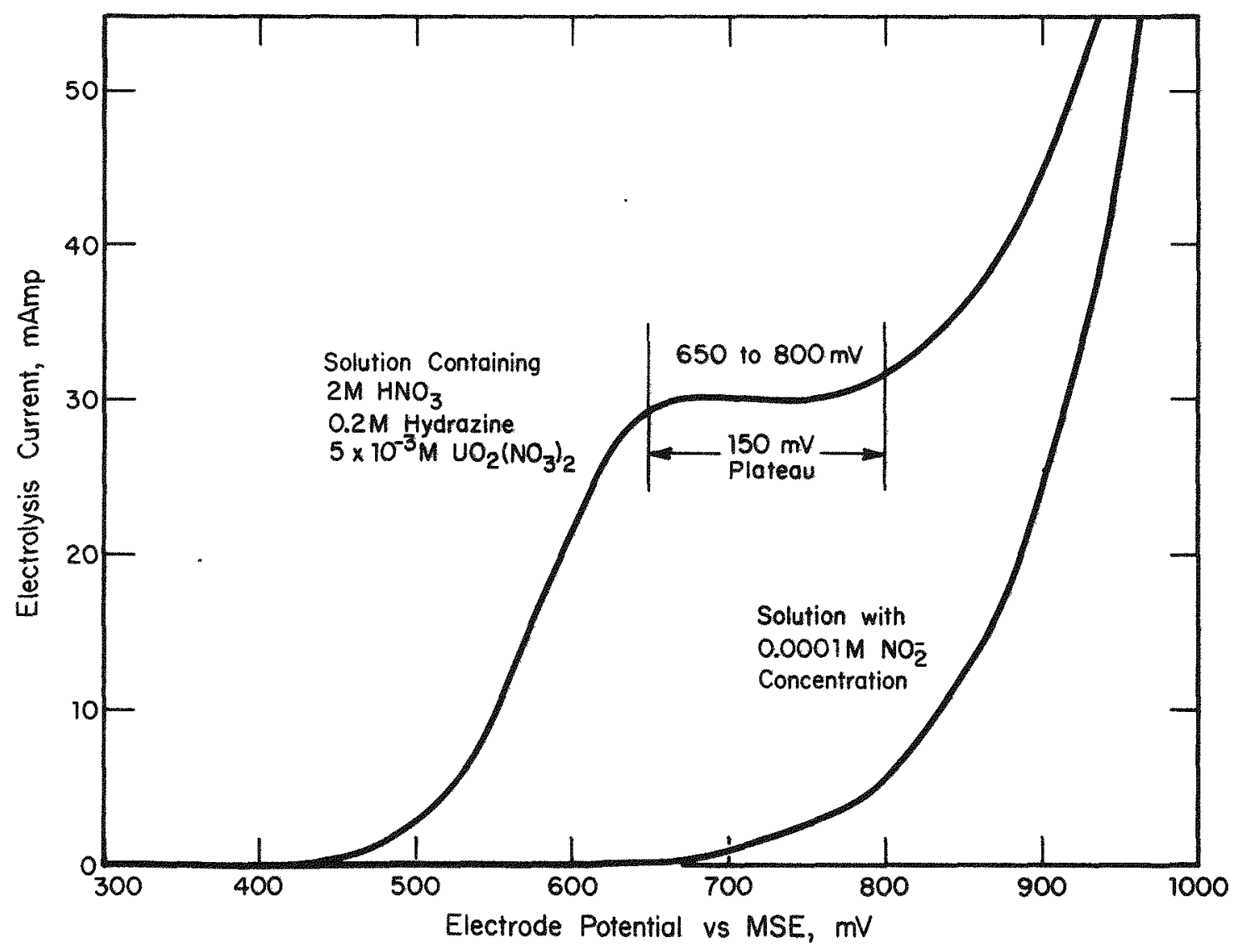

FIGURE 3. Voltammetric Curves for U(IV) Production in a Batch Electrolytic Cell Having Mercury-Coated Platinum-Mesh Electrodes 


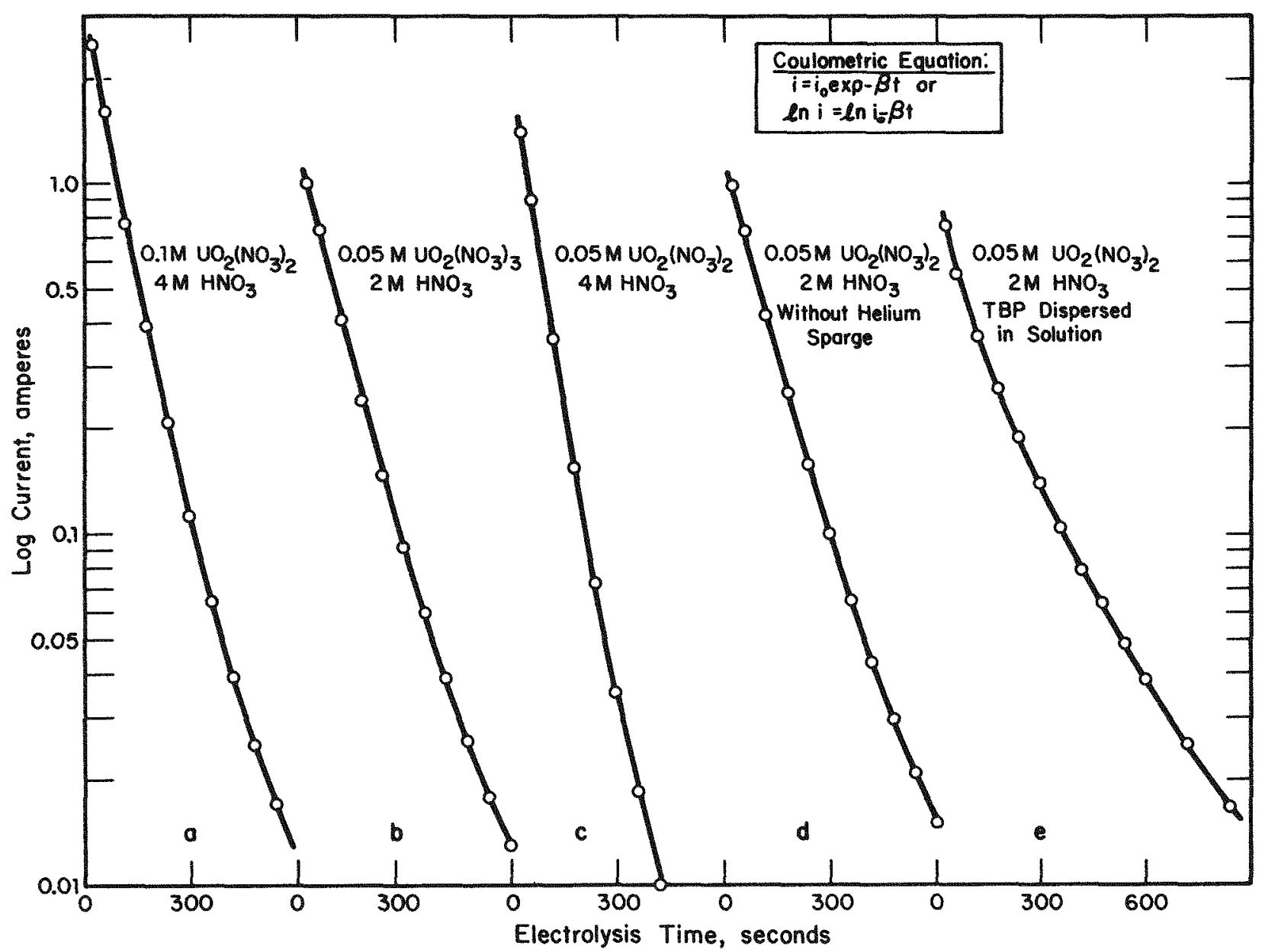

FIGURE 4. Decrease of Current with Time for Solutions of Various Uranium, Nitric Acid, Oxygen, and TBP Concentrations 
oxygen produces a small increase in residual current, and (4) that suspended organic matter can effectively lower the reaction rate, a1though a similar electrolysis with SRP 1EU (uranium product from solvent extraction) solution showed no deleterious effects from dissolved TBP.

The effect of acidity on the initial limiting current at constant uranium concentration is caused by the disproportionation process (Equation 3 ). At high acidities $(>4 M)$, the disproportionation process is fast compared to the rate for the uranyl mass transfer process. The uranyl ion reduction appears as a twoelectron process (Figure 4c). Aside from improved reaction kinetics, a high feed acidity is also necessary because the $\mathrm{H}^{+}$ion is consumed in the reduction of uranyl ion, and a minimum ( 1 molar) acidity is required in the product to prevent hydrolysis of uranous nitrate. Thus, acidity of a $1 \mathrm{M}$ uranyl nitrate solution must be $>3 \mathrm{M}$ initially if the final product is to be no less than $1 \mathrm{M}$ in free acid.

\section{Effect of Trace Metals}

Although no operational difficulties were encountered during work with SRP uranium product solutions, the concentration of trace metals at the MPPE by electrolysis can significantly reduce the operating lifetime of the MPPE.

Catalytic and other processes induced by trace metal deposits are well known. ${ }^{15}$ A typical process involving trace nitrites in the diffusion layer at the electrode surface would be

$$
\begin{aligned}
& \mathrm{M}^{2+}+\mathrm{Hg}+2 \mathrm{e} \rightarrow \mathrm{M}(\mathrm{Hg}) \\
& \mathrm{M}(\mathrm{Hg})+2 \mathrm{HNO}_{2}+2 \mathrm{HNO}_{3} \rightarrow 2 \mathrm{NO}+\mathrm{M}\left(\mathrm{NO}_{3}\right)_{2}+2 \mathrm{H}_{2} \mathrm{O} \\
& 2 \mathrm{NO}+\mathrm{HNO}_{3}+\mathrm{H}_{2} \mathrm{O} \rightarrow 3 \mathrm{HNO}_{2}
\end{aligned}
$$

followed by another cycle of electroreduction to give

$$
\mathrm{M}\left(\mathrm{NO}_{3}\right)_{2}+\mathrm{Hg}+2 \mathrm{e} \rightarrow \mathrm{M}(\mathrm{Hg})
$$

The net result of this catalytic process would be the production of increasing amounts of nitrous acid, which would eventually dissolve the mercury coating and thus lead to early failure. No such difficulties due to impurities were experienced with SRP-type uranium solutions. 


\section{Absence of Nitrite-Nitrate Reduction}

Neither nitrite or nitrate were reduced at the MPPE in the potential range of interest. This behavior is shown in Figure 3 where a $0.2 \mathrm{M}$ hydrazine-2M nitric acid solution containing $10^{-4} \mathrm{M}$ nitrite ion was scanned from the voltage necessary for mercury dissolution to the cathodic limit for hydrogen evolution.

The absence of interferences from nitrites and/or nitrates within the working range for the MPPE can be attributed to the presence of hydrazine in the electrolyte and to the irreversible nature of the nitrite and nitrate reactions ${ }^{16}$ Hydrazine scavenges nitrites by the following process

$$
\mathrm{N}_{2} \mathrm{H}_{5}{ }^{+}+\mathrm{HNO}_{2} \rightarrow \mathrm{HN}_{3}+\mathrm{H}_{3} \mathrm{O}^{+}+\mathrm{H}_{2} \mathrm{O}
$$

and

$$
\mathrm{HN}_{3}+\mathrm{HNO}_{2} \rightarrow \mathrm{N}_{2}+\mathrm{N}_{2} \mathrm{O}+\mathrm{H}_{2} \mathrm{O}
$$

Thus, the equilibrium concentration of nitrous acid in a $0.2 \mathrm{M}$ hydrazine-2M nitric acid solution will be quite small. In addition, the irreversible nature ${ }^{16}$ of the nitrite and nitrate reactions at the mercury electrode are such that any reduction currents due to these processes will be masked by the hydrogen evolution reaction. ${ }^{17}$

\section{Possibility of Azide Formation}

Azide is produced as an intermediate in the destruction of nitrites by hydrazine, ${ }^{10}$ and it forms an insoluble salt at the mercury electrode. ${ }^{18}$ Although azide behaves as a pseudohalogen and can be determined by stripping analysis, ${ }^{18}$ the potential for the reduction of mercurous azide is about $400 \mathrm{mV}$ anodic to the electrolysis potential for the reduction of uranium(VI). Therefore, no mercurous azide should be formed under the conditions in these experiments. No difficulties from azide formation were experienced, nor could the presence of azide be detected in the cell off-gas or in the space above an aged solution of uranous nitrate in nitric acid containing $0.2 \mathrm{M}$ hydrazine.

\section{CONTINUOUS-FLOW ELECTROLYSIS CELL}

\section{Cel1 Design}

The design and construction of the bench-scale, continuousflow, electrolysis cell were carefully considered so as to 
reprèsent a feasible engineering design. The cell body was constructed from acrylic polymer for easy observation of cathodic and anodic processes such as gassing and color changes. The cathode consisted of three 1 -in. $\times 4$-in. layers of 40 -gage platinum mesh. A single 1-in. $\times 4$-in. piece of 40-gage platinum mesh served as the anode.

The cathode and anode compartments were separated by a flexible Nafion ${ }^{(}$membrane. A positive-pressure differential ( 0.5 psi) across the Nafion $^{(3)}$ membrane held it in close contact with the cathode, thereby confining the flow in the cathode compartment to the channels within the platinum mesh. Dual salt bridge connections were provided for the reference electrode to minimize loss of potential control in case one of the bridges became blocked by a gas bubble. In operation, the feed stream to the cathode compartment was pulsed to improve the conversion efficiency and to assist in dislodging gas bubbles from the platinum mesh. The cell assembly is shown in Figure 5 .

The bench-scale, continuous-flow, electrolysis cell was evaluated for use with high acid ( $/ 3$ to $4 \mathrm{M} \mathrm{HNO}_{3}$ ) feed solutions where the uranyl ion reduction rate is governed by a pseudo first-order, two-electron process. The effects or uranium concentration, electrode area, electrode length, flow rate, and catholyte pulsing were described in terms of a mathematical mode1, and the results were used to estimate the size and power requirements for a plant-scale unit. The applicability of the bench-scale cell for processing SRP uranium solutions was shown in a demonstration run that lasted eight days.

\section{Mathematical Model}

The response of the bench-scale, continuous flow, electrolysis cell was best described in terms of a modified form of of the equation of Chu, Fleischmann, and Hi11.19

For a packed-bed electrode, where the residence time is much greater than the half-time for the electrode reaction, the exit concentration of the electroactive species is given by

$$
C_{L}=C_{0} \exp (-\ell / \lambda)
$$

where:

$$
C_{L}=\text { exit concentration, moles } / \mathrm{cm}^{3}
$$

() Registered tradename of E. I. du Pont de Nemours \& Co. (Inc), Wilmington, Delaware. 


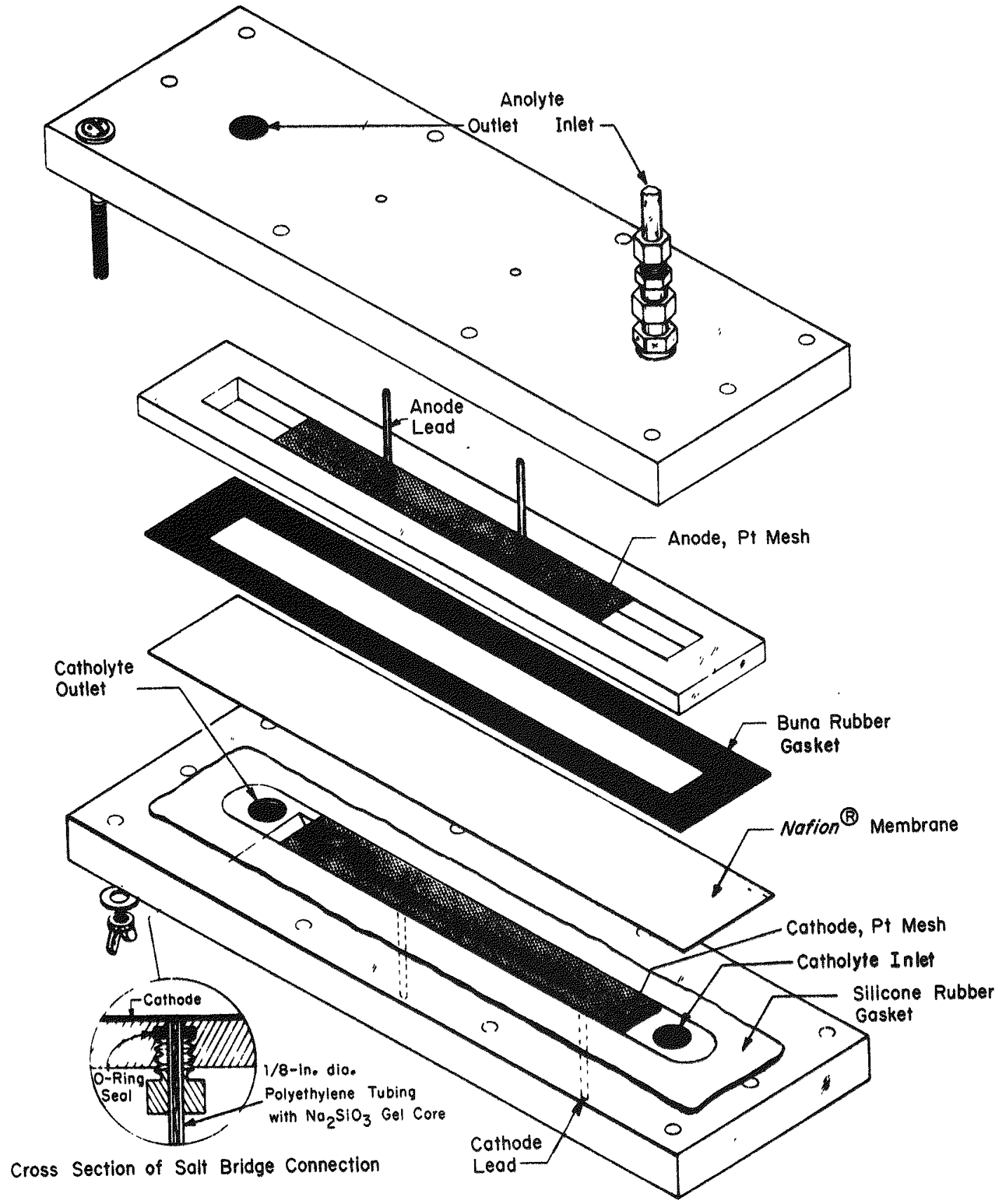

FIGURE 5. Assembly of the Bench-Scale, Continuous-Flow, Electrolys is Cell 


$$
\begin{aligned}
& { }^{C_{O}}=\text { initial concentration, moles } / \mathrm{cm}^{3} \\
& \ell=\text { electrode length, } \mathrm{cm} \\
& \lambda=\text { effective length, } \mathrm{cm}
\end{aligned}
$$

The effective length, $\lambda$, is given by

$$
\lambda=(\delta u / \varepsilon \alpha D a)
$$

where:

$\delta=$ diffusion layer thickness, $\mathrm{cm}$

$\mathrm{u}=$ flow rate, $\mathrm{cm}^{3} / \mathrm{sec}$

$\varepsilon=$ porosity factor, dimensionless

$\alpha=$ electrode area per unit volume, $\mathrm{cm}^{-1}$

$D$ = diffusion coefficient, $\mathrm{cm}^{2} / \mathrm{sec}$

$\mathrm{a}=$ cross-sectional area of cel1, $\mathrm{cm}^{2}$

Because $\delta$ is a function of volume flow rate $(u)$, it was convenient to have an expression for $\delta$ in terms of $u$. For stirred solutions, it has been shown ${ }^{14}$ that

$$
i_{\ell}=p \cdot R^{k}
$$

where:

$$
i_{\ell}=1 \text { imiting current }
$$

$R=$ stirrer speed

$p=a$ constant

$\mathrm{k}=\mathrm{a}$ constant

For stirred solutions, $i_{\text {e }}$ is proportional to $\delta^{-1}$; therefore, a similar relationship also should apply to packed-bed electrodes. A graph of $\lambda$ vs. $u$ for the data on packed-bed electrodes from Reference 12 gave

$$
\lambda=0.12 u^{0.619}
$$

Thus, by assuming a similar relationship between $\delta$ and $u$ for the bench-scale unit, Equation 10 was written as 


$$
\left.\mathrm{C}_{\mathrm{L}} / \mathrm{C}_{\mathrm{O}}=\exp \left[-(\varepsilon \alpha \mathrm{Da} \mathrm{l}) / \mathrm{pu}^{\mathrm{k}}\right)\right]
$$

where $\mathrm{p}$ and $\mathrm{k}$ are constants. The conversion efficiency is defined as

$$
\phi=\left(C_{0}-C_{L}\right) / C_{0}
$$

Thus Equation 14 can also be written

$$
\phi=1-\exp \left[-(\varepsilon \alpha \mathrm{Dal}) /\left(\mathrm{pu}^{\mathrm{k}}\right)\right]
$$

where $\phi$ is the conversion efficiency of the bench-scale unit.

\section{Effect of Uranium Concentration}

Equation 16 indicates that the conversion efficiency is dependent on the uranium concentration of the feed. This behavior is evident in the results of Table 1 . These results also indicate that the electrolysis current at constant flow rate is directly proportional to the uranyl ion concentration. This behavior is consistent with a diffusion-controlled, first-order, reduction process for high-acid feed solutions.

\section{TABLE 1}

Effect of Uranium Concentration on Conversion Efficiency

U(VI) in Feed, Flow Rate, U(IV) in Effluent, Current, Conv. moles mL/hr moles cmperes Eff., \%

$\begin{array}{lllll}0.205 & 20 & 0.184 & 0.191 & 89.8\end{array}$

$\begin{array}{lllll}1.002 & 20 & 0.901 & 0.987 & 91.3\end{array}$

\section{Effect of Electrode Area}

Equation 14 indicates that at constant flow, the logarithm of the fraction not electrolyzed, $\mathrm{C}_{\mathrm{L}} / \mathrm{C}_{\mathrm{O}}$, is proportional to the electrode area. This behavior is illustrated in Table 2 for wire-mesh and foil electrodes. The ratio of the geometric areas was 7.07 . 
TABLE: 2

Effect of Electrode Area

$\begin{array}{llllll}\begin{array}{l}\text { Potential, } \\ m V \text { vs MSE }\end{array} & \frac{P t \text { Foiz, } 13 \mathrm{~cm}^{2}}{C_{L} / C_{0}} \frac{l n}{\ln \left[C_{L} / C_{0}\right]} & \frac{92 \mathrm{~cm}^{2}}{C_{L} / C_{0}} \ln \left[C_{L} / C_{0}\right] & \begin{array}{l}\text { Ratio, } \\ \ln (\text { mesh)/ln(foiz) }\end{array} \\ 600 & 0.960 & -0.0408 & 0.742 & -0.298 & 7.3 \\ 650 & 0.930 & -0.0726 & 0.601 & -0.509 & 7.0 \\ 700 & 0.915 & -0.0888 & 0.533 & -0.629 & 7.1\end{array}$

These data were obtained by electrolyzing a $0.2 \mathrm{M}$ urany 1 nitrate solution with $1 / 2$-in. $\times 4$-in. wire mesh and foil electrodes installed in the bench-scale, continuous-flow, electrolysis cell. The flow rate was held constant at $5 \mathrm{~mL} / \mathrm{min}$ throughout the experiment, and neither electrode was plated with mercury. The results indicate that the geometric area of the electrode is an effective measure of the working area, and that wire mesh electrodes have an effective surface area which is several times that of of a foil electrode of equivalent size.

\section{Effect of Electrode Length}

The effect of electrode length is also given by Equation 14 . This equation shows that at constant flow rate, the ratio of $\ln \left[\mathrm{C}_{\mathrm{L}} \mathrm{C}_{0}\right]$ for two electrodes of different lengths should be proportional to their lengths, and that the ratio is independent of flow rate. This result is evident in Table 3 , where the ratio of $\ln \left[\mathrm{C}_{\mathrm{L}} / \mathrm{C}_{\mathrm{O}}\right]$ was determined as a function of flow rate for $1 / 2-i n . \times 2-i n$, and $1 / 2-i n, \times 4-i n$, foil electrodes.

\section{TABLE 3}

\section{Effect of Electrode Length}

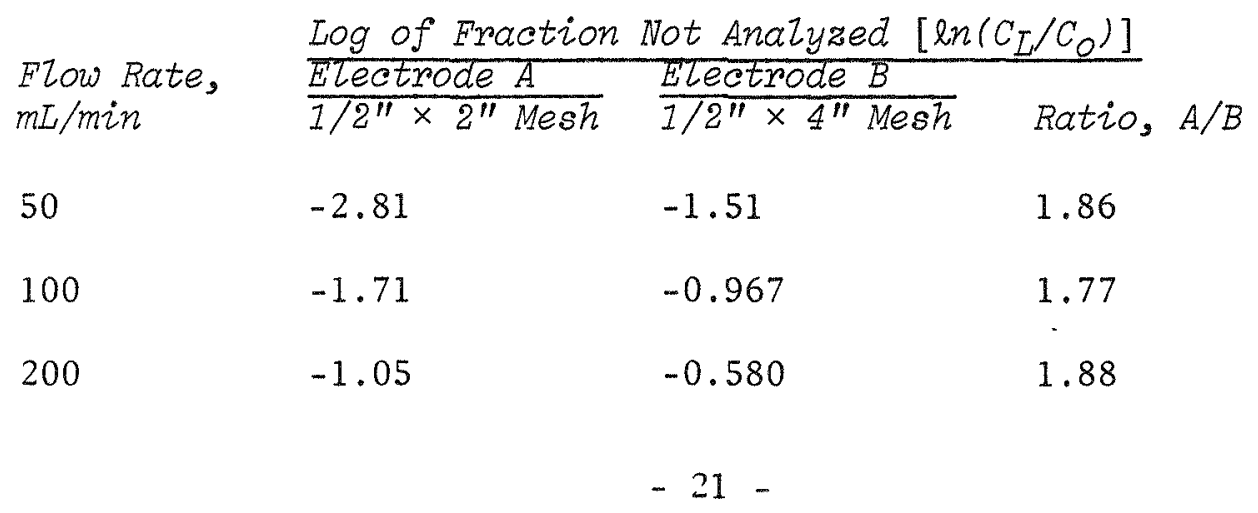




\section{Effect of Flow Rate}

The effect of flow rate was also determined by means of Equation 14. Equation 14 can be written to give

$$
u^{k}=-\varepsilon \alpha D a \ell /\left[p \cdot \ln \left(C_{L} / C_{0}\right)\right]
$$

because $0<\left(C_{L} / C_{O}\right)<1, \ln \left(C_{L} / C_{O}\right)$ is negative and the right-hand term is positive. Taking logarithms of both sides of Equation 17 gives

$$
\mathrm{k} \ln (\mathrm{u})=\ln (\varepsilon \alpha \mathrm{Da} a / \mathrm{p})-\ln \mathrm{z}
$$

where $Z$ is the absolute value of $\ln \left[C_{1} / C_{0}\right]$. A graph of $\ln \left|\ln \left(C_{L} / C_{0}\right)\right|$ vs. $\ln (u)$ is shown in Figure 6 .

The data points illustrated in Figure 6 were fitted to Equation 19:

$$
\ln \left|\ln \mathrm{C}_{L} / \mathrm{C}_{\mathrm{O}}\right|=\ln (\varepsilon \alpha \mathrm{Da} / \mathrm{p})-\mathrm{k} \cdot \ln u
$$

$D$ is known to be $\sim 6 \times 10^{-6} \mathrm{~cm}^{2} / \mathrm{sec}$; therefore, $\varepsilon, \alpha, a$, and $\ell$ could be easily measured, and the value for $p$ was readily calculated. Thus the values for $\mathrm{p}$ and $\mathrm{k}$ were $1.6 \times 10^{-3}$ and 0.514 , respectively.

Figure 7 illustrates the dependence of conversion ratio upon the flow rate for the bench-scale cell. The conversion ratio is almost linearly proportional to the $10 \mathrm{~g}$ of the flow rate over the range of $\sim 20$ to $90 \%$. Thus, this relationship can be used as a first approximation of cell performance.

\section{Effect of Feed Pulsing}

Superimposing a reciprocating motion upon the unidirectional flow of uranium solution through the cathode reduced the diffusion path and thus increased the reduction rate. Though the data reported here were obtained with only the minimal pulsing imparted by the metering pump, other tests demonstrated that increased turbulence to the solution within the cathode was beneficial. Not only was the conversion rate increased for a given flow rate, but the higher solution velocities dislodged gas bubbles from the cathode surface and maintained a more constant effective residence time. 


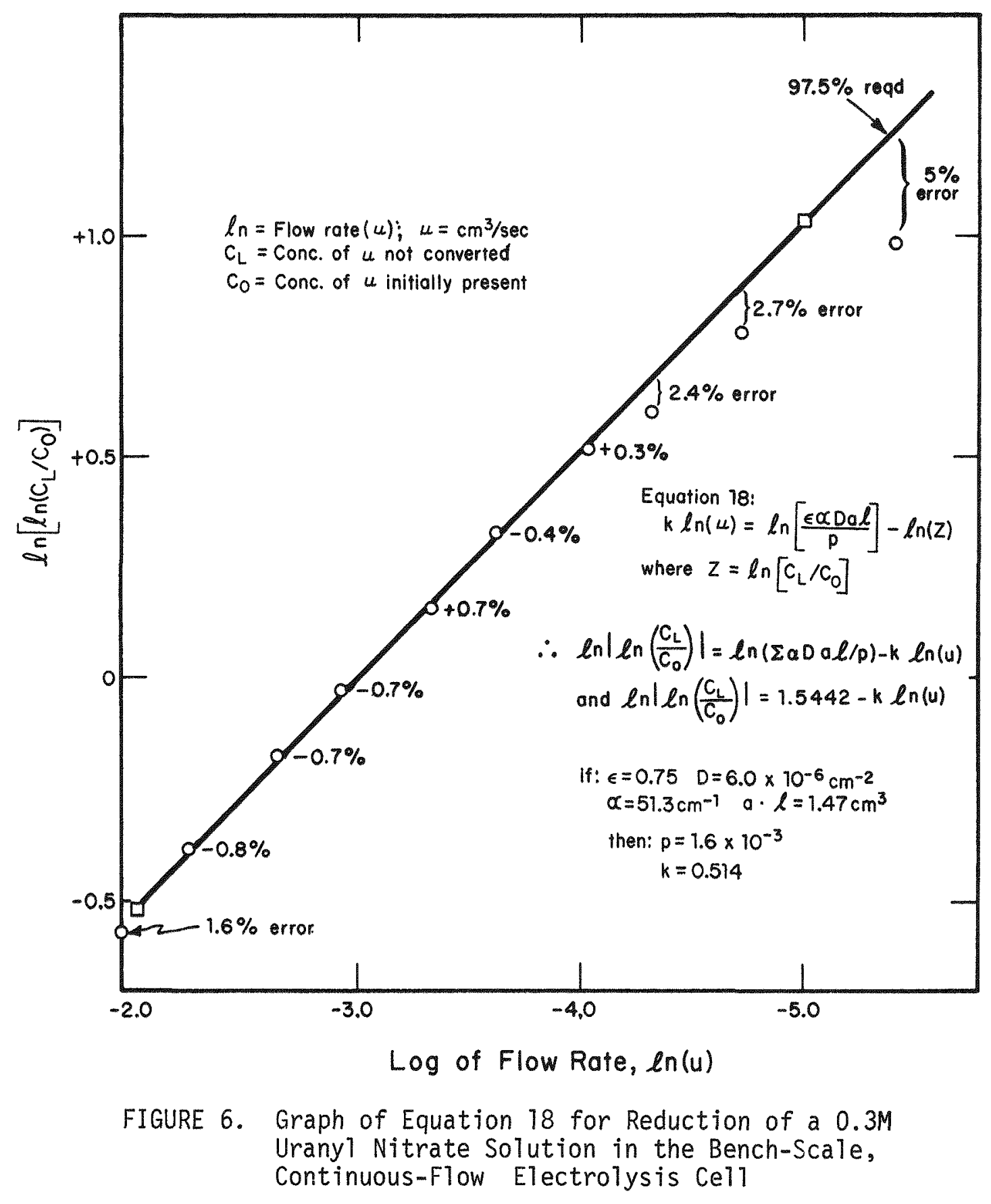




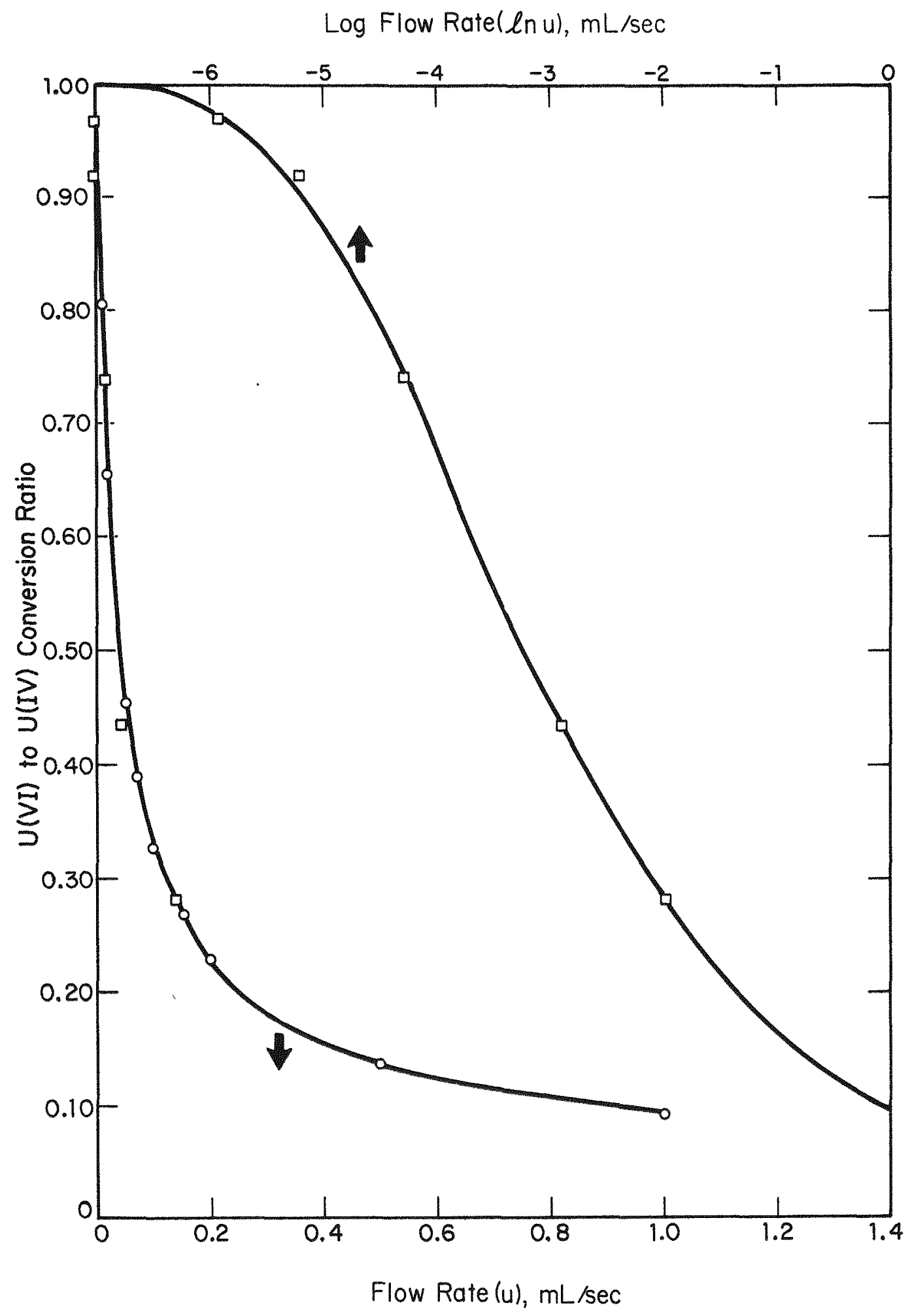

FIGURE 7. Conversion of Uranyl Nitrate to Uranous Nitrate in a Bench-Scale, Continous-Flow, Electrolys is Ce11 
However, this effect was difficult to quantize in a cell having a flexible membrane that dampened the imposed pulses. The additional expense required to design a cell with catholyte pulsing may not be justified by increased throughput alone. But pulsing as a means of dislodging gas bubbles from the cathode structure may be necessary for consistent operation.

\section{Endurance Test with SRP Uranium Process Solution}

The mercury-plated cathode structure was shown to maintain its enhanced overvoltage toward hydrogen reduction under continuous operation for 8 days, using actual reclaimed uranium solution from nuclear fuel. The feed solution for this test was the IEU product stream obtained directly from the SRP second uranium cycle of solvent extraction. This 1EU solution has a maximum concentration of $80 \mathrm{~g} \mathrm{U} / \mathrm{L}$ and is normally less than $0.1 \mathrm{M}$ in nitric acid. The concentration of the $19-\mathrm{L}$ batch of 1EU solution obtained for this test was $80 \mathrm{~g} \mathrm{U} / \mathrm{L}$.

After conditioning the 1EU solution for electrolysis by the addition of concentrated nitric acid and hydrazine, the feed composition was $64 \mathrm{~g} \mathrm{U} / \mathrm{L}(0.27 \mathrm{M}), 3 \mathrm{M} \mathrm{HNO}_{3}$, and $0.2 \mathrm{M} \mathrm{N}_{2} \mathrm{H}_{4}$. Over 17 liters of this feed were passed through the electrolytic cell over an 8-day period at an average rate of $1.5 \mathrm{~mL} / \mathrm{min}$.

The current efficiency was calculated to be $100 \%$ within experimental error for each simultaneous determination of flow rate, reduction current, and U(IV) concentration. However, the percent conversion of $U(V I) \rightarrow U(I V)$ varied throughout the test because: (1) the feed rate was changed several times, (2) gases accumulated on the mesh cathode, and (3) the potential of the reference electrode drifted over the period of the test. Observed conversions ranged from 30 to $99 \%$. No change in the visual appearance of the cathode structure was observed over the test.

To obtain stable operation over extended periods, duplicate reference electrodes should be provided as well as the duplicate salt bridges used in this test. The drift of the reference electrode experienced in this test resulted in a less-cathodic potential being applied to the cathode. Thus, no loss of current efficiency due to hydrogen reduction was experienced. However, a drift in the opposite direction would have generated excessive gases and caused premature termination of the endurance test.

DESIGN PARAMETERS FOR A PLANT-SCALE, CONTINUOUS-FLOW, ELECTROLYSIS CELL

Assuming an $80 \mathrm{~L} / \mathrm{hr}$ supply of $95 \%$-reduced $1 \mathrm{M}$ uranium solution is required, then Equation 16 can be modified to estimate the 
total cathode area of a plant-scale cel1. In Equation 16, the cathode volume represented by the product $a \cdot l$ can be as easiiy represented by the product of the cathode area (A) and the cathode thickness $(t)$ :

$$
\phi=1-\exp \left[(\varepsilon \alpha \mathrm{Dt} \mathrm{A}) / \mathrm{pu}^{\mathrm{k}}\right]
$$

Though the actual construction and design will determine the values of the specific surface area $(\alpha)$, the fractional void volume $(\varepsilon)$, and the cathode thickness $(t)$ required, these values can be estimated as $10 \mathrm{~cm}^{2}, 0.8 \mathrm{~cm}^{3}$, and $0.5 \mathrm{~cm}$, respectively, for the conservative 5-layer design illustrated in Figure 8. Using these values with the estimates of $\mathrm{p}$ and $\mathrm{k}$ found in this study, a cathode having $984 \mathrm{~cm}^{2}$ of area would be required. Though this area could be achieved in a single cathode $20 \mathrm{~cm} \times$ $50 \mathrm{~cm}\left(1000 \mathrm{~cm}^{2}\right)$, a stack of alternating anodes and cathodes is favored as an alternative design. Such a cell would draw $~ 4000$ amperes at about 2 volts, consuming about 8 kilowatts of power. However, only a small portion of the voltage is due to IR drops; therefore, the Joule heating in such a cell should be small enough to require no more than air cooling of the circulating anolyte solution.

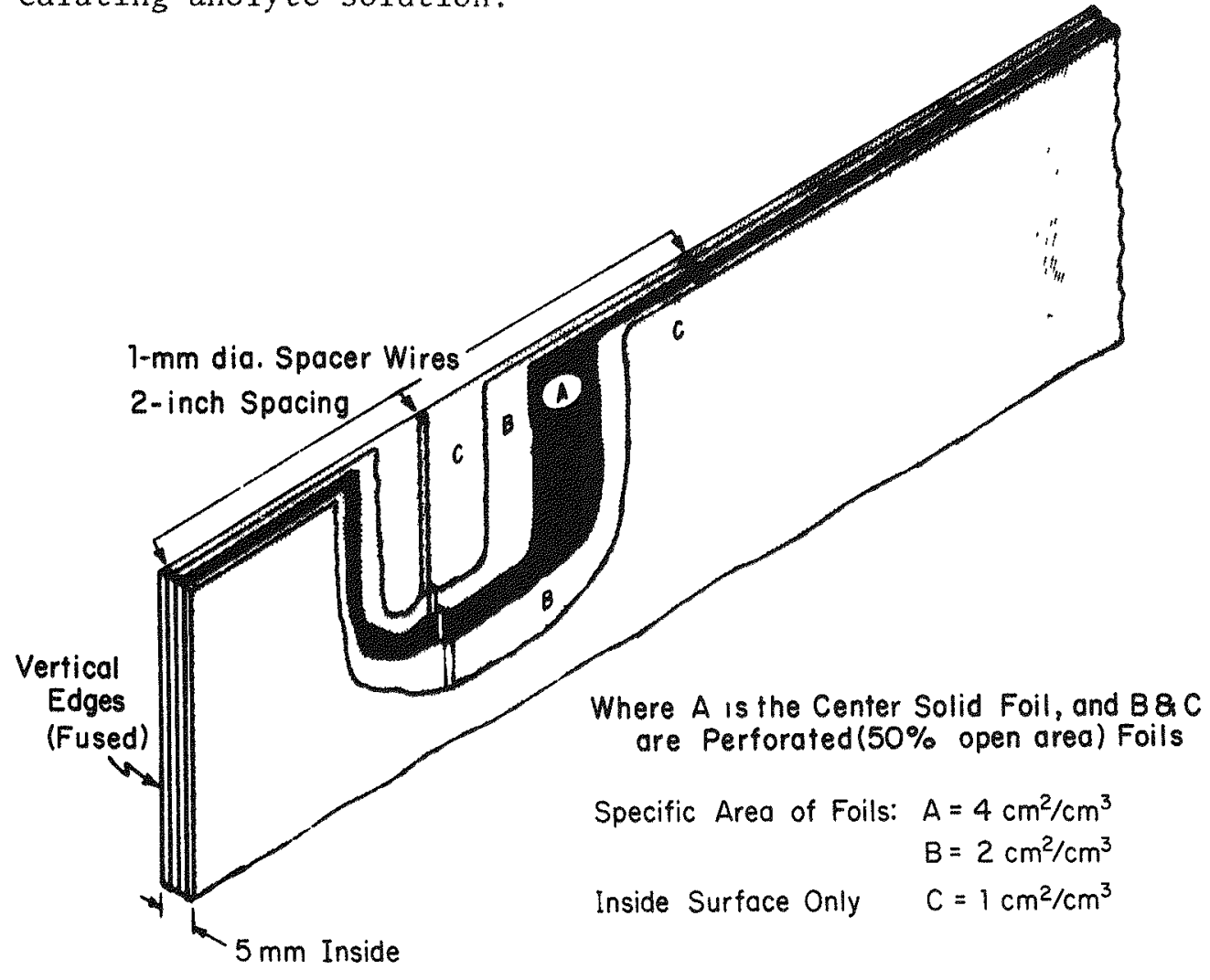

FIGURE 8. A Proposed Cathode Design for a Plant-Scale, Continuous-Flow Electrolysis Cell for Reducing $U(V I)$ to $U(I V)$ 


\section{REFERENCES}

1. C. S. Schlea, M. R. Caverly, H. E. Henry, and W. J. Jenkins. Uranium(IV) Nitrate as a Reducing Agent for Plutonium(IV) in the Purex Process. USAEC Report DP-808, E. I. du Pont de Nemours and Co. (Inc.), Savannah River Laboratory, Aiken, South Carolina (1963).

2. R. J.W. Streeton and E. N. Jenkins. The Preparation, Stabizization and Analysis of Uranium(IV) Nitrate Solutions. UKAEA Report AERE-R3938, United Kingdom Atomic Energy Authority, Atomic Energy Research and Development Establishment, Harwel1, Berkshire, England (1962).

3. H. Schmieder, F. Baumgartner, H. Goldacker, H. Hausberger, and E. Warneke. "Electrolytic Methods for Application in the Purex Process," in Proceedings of the International Solvent Extraction Conference 1974, Vol. 3, Society of Chem. Ind., London, England (1974).

4. G. S. Nichols. Electrolytic Preparation of Uranous Nitrate. USAEC Report DP-1065, E. I, du Pont de Nemours and Co. (Inc.), Savannah River Laboratory, Aiken, South Carolina (1966).

5. E. Lopez-Menchero, L. Gehem, H. Eschrich, P. Hansen, J. Centeno, and R. Aerts. Study of Uranizm(IV) Nitrate as a Reductant for Plutonium. Eurochemic Technical Report No. 118, NP-17197(ETR-180), European Company for the Chemica1 Processing of Irradiated Fue1s, Mo1, Belgium (1966).

6. M. B. Finlayson and J. A. S. Mowat. "Electrolytic Reduction of Uranium(VI) and Plutonium(IV) Nitrate Solutions:

Development of a Continuous Process:" Electrochem. Technol., 3,148 (1965).

7. W. Davies, W. Gray, and K. C. Mcleod. "Coulometric Determination of Uranium with a Platinum Working Electrode." Talanta 17, 937 (1970).

8. C. C. Hsiang and C. T. Chang. "The Electrolytical Reduction of Uranyl Ion Using an Ion Exchange Membrane." J. Inorg. Nucl. Chem. 37, 1949 (1975). 
9. T. M. Florence. "Anodic Stripping Voltammetry with a Glass Carbon Electrode Mercury-P1ated in Situ!" J. Electroanal. Interfacial Chem. 27, 273 (1970).

10. J. R. Perrott and G. Stedman. "The Kinetics of Nitrite Scavenging by Hydrazine and Hydrazoic Acids at High Acidities." J. Inorg. Nucl. Chem. 39, 325 (1977).

11. A. M. Hartley, A. G. Hiebert, and J. A. Cox. "Preparation and Properties of a Platinum Based Mercury Film Electrode." J. Electroanal. Chem., 17, 81 (1968).

12. G. D. Robbins and C. G. Enke. "Investigation of the Compound Formed at a Platinum Mercury Interface." $J$. Electroanal. Chem. 23, 343 (1969).

13. W. R. Heineman and T. Kuwana. 'Mercury-Platinum Optically Transparent Electrode." Anat. Chem. 43, 1075 (1971).

14. P. Delahay. New Instrumental Methods in Electrochemistry. Interscience, New York, p. 284 (1954).

15. Electroanalytical Chemistry. A. J. Bard, Editor, Vol. 8. Marce1 Dekker, Inc., New York, p. 99 (1975).

16. K. J. Better. Electrochemical Kinetics. S. Bruckenstein and B. Howard, Translation Editors. Academic Press, New York and London, p. 490 (1967).

17. R. J. Davenport and D. C. Johnson. "Voltammetric Determination of Nitrate and Nitrite Ions Using a Rotating Cadmium Disc Electrode." Anal. Chem. 45, 1979 (1973).

18. L. F. Durding, D. M. Lukaszewski, and F. D. Sancillo. "Quantitative Polarographic Determination of Azides in Cobalt(III) Coordination Complexes." Anal. Chem. 47, 176 (1975).

19. A. K. P. Chu, M. Fleishmann, and G. J. Hill. "Packed-Bed Electrodes. I. The Electrochemical Extraction of Copper Ions from Dilute Aqueous Solutions:" J. Appl. EZectrochem. 4, 323 (1974). 